\title{
KEARIFAN LOKAL MASYARAKAT KABUPATEN MADIUN DALAM MENYIKAPI PANDEMI COVID-19
}

\author{
Muhammad Hanif $\left({ }^{*}\right.$ *) \\ ${ }^{1}$ Master of Social Science Education, Postgraduate, Universitas PGRI Madiun, Indonesia
}

\section{ARTICLE INFORMATION}

$\begin{array}{ll}\text { Submitted } & : 12^{\text {th }} \text { November, } 2020 \\ \text { Review } & : 28^{\text {th }} \text { April, 2021 } \\ \text { Accepted } & : 10^{\text {th }} \text { May, 2021 } \\ \text { Published } & : 07^{\text {th }} \text { June, } 2021 \\ \text { Available Online } & : \text { June, } 2021\end{array}$

\section{KEYWORDS}

Local Wisdom; Madiun; the Covid-19 Pandemic.

\section{CORRESPONDENCE}

*E-mail: hanif@unipma.ac.id

\section{A B S T R A C T}

Covid-19 pandemic has caused massive and widespread fear from various walks of life. The Covid-19 outbreak has affected all aspects of human life. This social reality encourages the people of Madiun Regency to make an effort to respond the pandemic by relying on local wisdom. The purpose of the study is to analyze and explain the actions of the people of Madiun Regency in responding to the Covid-19 Pandemic. The study was conducted for a year using a qualitative ethnographic approach. Data were collected by doing interview, observation, and document recording. The informants were determined by the purposive sampling technique. Meanwhile, the data analysis was using coding techniques. The results show that the community carries out mitigation through various activities vertically (supernatural powers) and horizontally (fellow humans and nature) in accordance with the philosophy of life of personal memayu hayuning, memayu hayuning kulawarga, memayu hayuning together, memayu hayuning bawana, including; (1) doing religious rituals, (2) carrying out 'peduli tangga teparo' (a caring-neighbor movement), (3) encouraging mutual cooperation in various aspects of life fulfillment with the principles of togetherness, mutual honing, compassion, and upbringing, (4) activating and mobilizing food barns and barns food storage, and growing medicinal plants and consuming them to increase immunity.

\section{A. PENDAHULUAN}

C orona Virus Disease 2019 atau Covid-19 memiliki dampak yang luas terhadap kehidupan umat manusia. Virus yang muncul di Wuhan Cina pada bulan Desember 2019 ini kemudian merebak tidak hanya di dalam negeri Cina tetapi hampir sebagian besar masyarakat dunia termasuk Indonesia. Mengingat epidemi yang terjadi pada skala luas, melintasi batas internasional, mengakibatkan banyak orang yang terpapar dan menimbulkan kurban jiwa.

Sikap sebagian besar masyarakat Kabupaten Madiun Propinsi Jawa Timur Indonesia terhadap pandemi Covid-19 beraneka ragam. Sebelum tanggal 2 Maret 2020 masyarakat secara umum masih santai, tidak respek, bahkan menjadikan Covid-19 sebagai tema humor. Contohnya; corona diplesetan menjadi "komunitas rondo mempesona" (komunitas janda mempesona), "komunitas rondo merana", bahkan ada yang membuat lagu dangdut dengan judul "Komunitas Rondo Merana". Lagu dangdut tersebut sempat viral di youtube namun kemudian dihapus karena banjir kritikan dari para netizen. Lagu tersebut dianggap tidak berempati pada pekerja urban, tidak sensitif, dan sejenisnya (Fanani, 2020). Masih banyak lagi contoh lainnya, baik yang berupa akronim, maupun gambar. Namun setelah tersiar berita ada 2 (dua) warga Indonesia positif Covid-19, sikap masyarakat mulai resah dan ada yang gaduh.

Masyarakat Kabupaten Madiun tidak sedikit yang baru sadar bahwa Covid-19 sudah berada di sekitarnya. Ketidaksiapan masyarakat menghadapi Covid-19 tercermin dalam berbagai bentuk ketakutan, kecemasan, dan kepanikan terutama dari kalangan kelas ekonomi menengah. Salah satu contohnya warga masyarakat bersikap tergesa-gesa dan cenderung gagap dengan melakukan panic buying. Mereka memborong barang-barang agar bisa terhindar dari kekurangan pangan dan dapat bertahan hidup. Selain itu Covid-19 juga berimbas pada interaksi sosial yang semula bersahaja berubah menjadi serba canggung, menghindari tegur sapa, 
menaruh curiga pada orang lain, dan lain sebagainya.

Warga masyarakat Kabupaten Madiun ada yang menilai bahwa pandemi Covid-19 yang berimbas pada berbagai aspek kehidupan masyarakat ini sebagai sebuah realitas sosial yang harus disikapi dan diarifi. Mereka prihatin melihat realitas sosial ini, kemudian muncul pemikiran dan strategi untuk mengatasi dampak akibat persebaran Covid-19 dan berusaha membantu warga masyarakat agar memiliki kemampuan dan kebijaksanaan dalam menyikapi pandemi Covid-19. Salah satu yang dijadikan sandaran dan pijakannya yaitu kearifan lokal (local wisdom).

Kearifan lokal merupakan unsur-unsur dari budaya yang mengkristal menjadi bagian-bagian yang menyemai tatanan fisik maupun non fisik dari suatu kebudayaan masyarakat atau bangsa (Habibi, R.K., Kusdarini, 2020). Bagian atau unsur-unsur tersebut menjadi konsepsi tentang hidup dan kehidupan. Konsepsi tersebut sebagai hasil pemikiran yang mendalam dan mengandung nilainilai yang dijadikan padangan hidup dan rujukan warga masyarakat pendukungnya dalam menjalani hidup (Geertz, 1983). Wales (1958) juga menyampaikan hal serupa yaitu "the sum of the cultural characteristic which the vast majority of a people have in common as a result of their experiences in early life".

Penjelasan di atas dipertegas oleh Karo (dalam Theresia, 2014). la menyampaikan bahwa kearifan lokal adalah pandangan-pandangan yang bijaksana dari sebuah masyarakat lokal. Pandangan pandangan sebagai pengejawantahan dari kearifan lokal tersebut oleh Mujahidin (2016) dimaknai sebagai prinsip-prinsip menjalani hidup yang dipedomani dan diimplementasikan oleh masyarakat lokal. Prinsip-prinsip tersebut diwujudkan dalam tata nilai dan norma-norma. Dengan demikian kearifan lokal ini tidak hanya menjaga tradisi atau adat-istiadat yang diwariskan secara turun-temurun akan tetapi juga memberikan sejumlah tata kelola hidup yang baik dan selaras dengan lingkungan sosial dan alam, serta dengan sang maha pencipta (Ismail, Bakhtiar, Yanis, Darisma, Abdullah, 2020).

Untuk mendapatkan gambaran yang lebih dalam tentang kearifan lokal dalam suatu masyarakat maka perlu kiranya menelaah kebudayaannya. Hal tersebut dikarenakan kearifan lokal pada hakikatnya adalah sesuatu yang memiliki nilai-nilai budaya yang baik yang sebenarnya sudah diajarkan semenjak lama dari nenek moyang secara turun temurun (Casram, Dadah, 2019). Darmastuti (2012) juga menyampaikan bahwa budaya dan manusia (masyarakat) memiliki hubungan yang erat dan berguna untuk menginternalisasi, nilai dan mensosialisasikannya, mengenkulturasi dan melahirkan perilaku. Koentjaraningrat (2009) jauh sebelumnya sudah menegaskan bahwa budaya di dalamnya terdapat sistem nilai yang berupa konsepsi hidup yang bernilai dan digunakan sebagai pengarah dan orientasi kehidupan bagi masyarakat pendukungnya.

Budaya tumbuh bersama masyarakat pendukungnya sehingga budaya dengan manusia (masyarakat) memiliki hubungannya yang sangat erat, tidak mungkin ada kebudayaan tanpa manusia, dan sebaliknya tidak ada manusia yang tidak berkebudayaan. Tumbuh kembangnya kebudayaan tidak serta merta namun secara gradual, dimulai dari usage, folways, mores, custom, culture, hingga civilitation. Lahir dan perkembangan budaya ini menurut pandangan Soekanto S. dan Sulistyowati (2014) sebagai suatu hasil belajar yang membuahkan pengetahuan dan pengalaman. Pengetahuan dan pengalaman itu digunakan untuk menginterprestasikan nilai dan melahirkan sikap, tingkah laku, dan perilaku. Nilai yang terkandung dalam budaya tersebut oleh masyarakat pendukungnya digunakan untuk memahami dirinya sendiri dan lingkungannya. Hal tersebut sejalan dengan pendapat C. Kluckhohn dan F. Kluckhohn bahwa orientasi nilai budaya pada hakikatnya mencakup hakikat diri manusia, karya, posisi manusia dalam ruang dan waktu, serta hubungan manusia dengan lingkungan sekitar (Kluckhohn, 1991).

Untuk mengetahui hal-hal apa saja yang dilakukan masyarakat dalam menyikapi pandemi Covid-19 maka perlu kiranya menelaah batasanbatasan menurut falsafah berdasarkan kearifan lokal masyarakatnya. Kearifan lokal ini berhubungan dengan pengetahuan, dan pengetahuan tersebut berkembang melalui proses belajar dan bekerja dalam pemenuhan kebutuhan hidup, baik jasmani dan rohani (Soetomo, 2012; Darmastuti, 2012). Kearifan lokal sebagai hasil budaya memberi kerangka referensi dan pijakan masyarakat pendukungnya untuk menyikapi segala hal yang terjadi di dalam hidup dan kehidupan (Ting-Toomey dalam Raharjo, 2005). Hanif dan Retno (2019) menegaskan pula bahwa kearifan lokal ini bagi masyarakat berfungsi sebagai rujukan atau referensi, pedoman, pengontrol, dan rambu-rambu untuk bersikap, bertingkah laku dan berperilaku dalam berbagai dimensi kehidupan, baik saat berhubungan dengan yang maha hidup (Tuhan), dengan sesama manusia maupun dengan alam. Fungsi kearifan lokal juga disampaikan oleh Hannan dan Trianingsih (2020) yaitu; 1) sebagai konservasi dan pelestarian sumberdaya alam; 2) untuk mengembangkan sumber daya manusia; 3) untuk pengembangan kebudayaan dan ilmu pengetahuan; 4) sebagai petuah, kepercayaan dan pandangan hidup. Sedangkan bentuk-bentuk kearifan lokal di antaranya berupa: ajaran-ajaran, nilai, norma, etika, kepercayaan, adatistiadat, hukum adat, dan lain-lainnya.

Sikap merupakan respon terhadap stimulus dan menjadi faktor yang mempredisposisi masyarakat bertindak dan melaksanakan perilaku tertentu 
(Strickland dalam Hanurahman, 2012). L.L. Thursione (dalam Ahmadi, 2007) juga mengatakan bahwa sikap adalah kecenderungan ketika berhubungan dengan obyek. Sedangkan makna menyikapi dalam kajian ini yaitu mengambil atau menentukan sikap terhadap sesuatu, dalam konteks ini sikap terhadap obyek yaitu hal-hal yang ada hubungannya dengan situasi dan kondisi pandemi Covid-19.

Sikap tersebut di atas sebagai wujud kesadaran individu dalam melaksanakan kegiatan-kegiatan yang berhubungan dengan suatu yang terjadi di lingkungan sekitar. Jika sikap ini diarahkan sebagai sikap masyarakat maka maknanya menjadi suatu kesadaran kelompok orang atau warga yang berada dalam lokalitas tertentu, berinteraksi secara kontineu, dan menghasilkan kebudayaan. Sikap masyarakat tersebut ditandai dengan berbagai bentuk aktivitas terhadap obyek dan dilakukan secara berulangulang. Obyek yang dimaksud yaitu segala sesuatu yang ada kaitannya secara langsung atau tidak langsung dengan Covid-19.

Sikap masyarakat terhadap suatu obyek secara garis besar dikelompokan menjadi dua, yaitu sikap positif dan sikap negatif. Sikap positif merupakan sikap yang menunjukkan kearifan dan ikhtiar dalam menyikapi pandemi Covid-19. Sedangkan sikap negatif merupakan sikap yang tidak arif dan tanpa ikhtiar. Baron\&Byrne (2004) menyampaikan sikap ini meliputi kognitif, afektif, dan psikomotor yang ketiganya saling berhubungan.

Sikap masyarakat tersebut di atas terbentuk melalui proses belajar dan interaksi dengan lingkungannya, dan berfungsi sebagai pengarah masyarakat dalam mewujudkan tujuan dan menghindari hasil yang tidak diinginkan, menjaga harga diri, alat aktualisasi diri, dan lain sebagainya (Rahman, 2013). Adapun faktor-faktor determinan yang mempengaruhinya menurut Walgito (2011) yaitu fisiologis, pengalaman langsung terhadap objek sikap, pengalaman, situasi, normna, kerangka acuan, dan komunikasi sosial. Greenberg \& Baron (2003) juga mengatakan faktor utama pembentuk sikap yaitu (1) faktor predisposisi yang berupa kecenderungan ke arah suatu perkembangan tertentu, meliputi keyakinan dan norma, (2) faktor pemungkin yang mengkatalisator sikap, tindakan, dan perilaku, meliputi pengetahuan, kondisi kultur, ekonomi, dan sosial, (3) faktor penguat yang mendorong atau memperkuat terjadinya sikap, tindakan, dan perilaku sosial, seperti tokoh panutan, penyuluhan, dan media massa.

Dengan demikian, penelaahan tentang kearifan lokal suatu masyarakat perlu kira mendalami juga budayanya karena budaya mengandung nilai-nilai, dan nilai-nilai tersebut mempredisposisi sikap, tingkah laku dan perilaku manusia dalam menyikapi pandemi Covid-19.

\section{B. METODE PENELITIAN}

$\mathrm{P}$ enelitian ini menggunakan pendekatan kualitatif etnografis. Pendekatan etnografis merupakan cara untuk mendalami perilaku yang terjadi secara alami di sebuah budaya atau sebuah kelompok sosial tertentu (Creeswell, 2014). Dalam penelitian ini yang diungkap dan didalami yakni sikap dan tindakan masyarakat Kabupaten Madiun dalam menghadapi pandemi Covid-19.

Penelitian ini dilaksanakan di Kabupaten Madiun selama satu tahun (bulan Januari 2020-Desember 2020). Sumber penelitian menggunakan sumber primer yang berupa informasi dari para informan dan hasil pengamatan secara langsung, serta sumber skunder yang berupa dokumentasi, laporan kegiatan, dan sejenisnya. Adapun penentuan informan dengan teknik purposive sampling. Penentuan informan dalam penelitian ini menggunakan teknik purposive sampling yakni teknik mengambil informan disesuaikan dengan tujuan atau tema penelitian dan dianggap memiliki informasi yang diperlukan bagi penelitian. Sedangkan pengumpulan datanya menggunakan wawancara, observasi, pencatatan dokumentasi. Untuk memeriksa validitas data, peneliti menggunakan teknik triangulasi sumber. Sedangkan analisis datanya dengan Teknik Coding Model Strauss dan Corbin (1990) yaitu open coding, axial coding, dan selective coding.

\section{HASIL DAN PEMBAHASAN 1. Hasil Penelitian}

$\mathrm{K}$ abupaten Madiun merupakan wilayah Propinsi Jawa Timur bagian barat daya dan perbatasan dengan Kabupaten Ngawi di sebelah barat, Kabupaten Bojonegoro di sebelah Utara, Kabupaten Nganjuk di sebelah Timur, dan Kabupaten Ponorogo di sebelah Selatan. Kabupaten Madiun terdiri dari 198 desa, 8 kelurahan, dan 15 kecamatan. Jumlah penduduk Kabupaten Madiun pada tahun 2017 berjumlah 727.994 jiwa dan luas wilayahnya 1.010,86 $\mathrm{km}^{2}$ dengan sebaran penduduk 701 jiwa $/ \mathrm{km}^{2}$. Sedangkan kehidupan masyarakatnya pada sektor pertanian dan budaya masyarakatnya lebih banyak bercorak agraris (BPS, 2020).

Hasil wawancara dengan para informan dan hasil observasi dapat ditarik benah merahnya bahwa Pandemi Covid-19 merupakan pageblug sebagaimana yang pernah dialami oleh generasi pendahulunya. Mereka berkeyakinan bahwa salah satu faktor yang menyebabkan terjadinya pageblug Covid-19 yaitu adanya disharmoni hubungan antar kosmis dan hubungan manusia dengan lingkungannya, baik lingkungan sosial maupun alam. Untuk itu selain melakukan tindakan-tindakan yang sesuai protokol kesehatan (prokes) Covid-19 yang berupa 5M (memakai masker, mencuci tangan paai sabun dengan air mengalir, menjaga jarak, menjauhi kerumunan, membatasi mobilisasi dan interaksi) masyarakat juga menyikapinya dengan berbagai 
tindakan. Tindakan-tindakan tersebut dengan mendasarkan pada falsafah hidup yang adiluhung (mengandung nilai-nilai keutamaan) yaitu memayu hayuning pribadi, memayu hayuning kulawarga, memayu hayuning sasama, memayu hayuning bawana (berbuat baik bagi diri sendiri, keluarga, sesama manusia, makhluk hidup dan seluruh dunia). Falsafah tersebut diimplementasikan ke dalam berbagai bentuk kegiatan atau aktivitas, diantaranya:

\section{a. Ritual keagamaan}

Ritual keagamaan merupakan hal-hal yang berkaitan dengan tata cara upacara keagamaan (ritus). Ritual dilaksanakan berdasarkan keyakinan dan kepercayaan masyarakat setempat dalam mendekatkan diri kepada kekuatan ghaib, yang maha tinggi di atas manusia atau Tuhan agar terhindar dari Covid-19 yang membahayakan bagi kelangsungan hidupnya.

Masyarakat Kabupaten

Madiun menyelenggarakan ritual tolak bala Covid-19 (menangkal bahaya, bencana, penyakit akibat Covid19) dengan ritus yang beraneka cara. Ritual tolak bala yang diselenggarakan oleh warga masyarakat beraneka ragam dan jumlahnya sangat banyak. Hampir di semua desa melaksanakan kegiatan tolak balak. Kegiatan ritual dilaksanakan berdasarkan agama dan kepercayaan masing-masing. Diantaranya sebagai berikut:

1) Perteguh toleransi, ketaqwaan dan bermunajat.

Rohaniawan atau pemuka-pemuka agama sepakat dan bahu membahu melakukan mitigasi dengan melakukan memperteguh toleransi, meningkatkan ketaqwaan dan bermunajat (berdoa). Hal tersebut sebagaimana yang dilakukan Forum Kerukunan Umat Beragama Kabupaten Madiun (FKUB). FKUB mengintenkan komunikasi dan koordinasi untuk memperkuat keimanan para jamaahnya, toleransi antar pemeluk agama agar tercipta ketentraman dan kedamaian. Iktiar ini disambut baik oleh banyak kalangan termasuk rohaniawan. Hal tersebut sebagaimana disampaikan oleh imam masjid Nglames Madiun, masjid Banjarsari Dagangan, masjid Kebonsari dan lainlainnya. Para imam masjid tersebut selalu menindaklanjutinya dengan menyerukan kepada jamaahnya untuk meningkatkan ibadahnya, baik ibadah secara vertikal maupun horisontal (hablum minallah dan hablum minnas).

Rohaniawan atau pemuka-pemuka agama dan aliran kepercayaan juga melaksanakan ritual berdasarkan agama dan kepercayaan masingmasing dengan memperhatikan dan melaksanakan protokol kesehatan. Contohnya di kalangan umat Islam, para khatib Sholat Jumat senantiasa mengajak dan menyerukan agar para jamaah senantiasa meningkatkan iman, bersuci, dan hal-hal lainnya yang berkaitan dengan protokol kesehatan. Para pengurus takmir masjid melaksanakan istighosah. Selain itu para imam sholat wajib lima waktu di berbagai mushola dan masjid melaksanakan atau memanjatkan doa tolak balak. Hal tersebut sebagaimana yang dilakukan di masjid Kecamatan Wonoasri, Kecamatan Sawahan, dan di berbagai kecamatan lainnya di Kabupaten Madiun. Di masjidmasjid tersebut, para imam sholat wajib lima waktu pada rakaat terakhir membaca doa gunut nazilah bala. Kegiatan istighosah dan doa qunut tersebut ini sebagai permohonan atau minta pertolongan Allah SWT agar terhindar dari segala bentuk bencana dan malapetaka, termasuk Covid-19.

\section{2) Oboran}

Warga masyarakat Desa Sirapan Kecamatan Madiun menyikap pandemi Covid-19 dengan melaksanakan ritual tolak bala dengan oboran. Oboran merupakan obor yang terbuat dari bambu, berbahan bakar minyak kelapa, dan ditanjapkan di halaman rumah warga masyarakat.

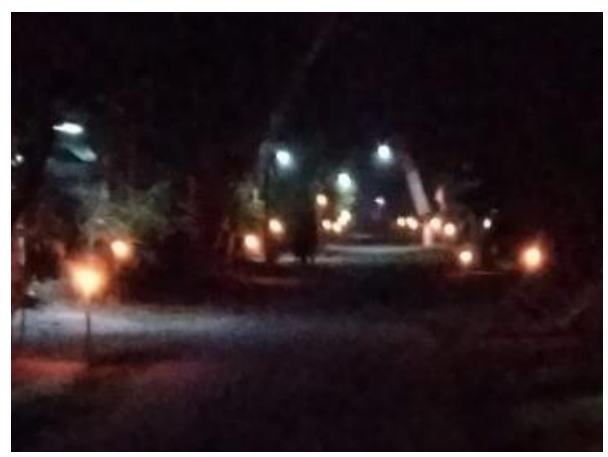

Gambar 1. Obor menyala dipancangkan di depan rumah warga Desa Sirapan (Sumber: Koleksi Peneliti)

Pelaksanaan oboran dilaksanakan oleh seluruh warga masyarakat Sirapan selama sepekan dan tidak boleh dipadamkan. Jika padam, warga berkewajiban memperbaikinya seperti mengisi minyak dan atau memperbaikinya agar tetap menyala sepanjang hari dalam sepekan.

Kegiatan oboran ini oleh masyarakat dirangkai dengan pelaksanaan ritual tolak balak (upacara bersih desa) dan upacara sedekah bumi. 


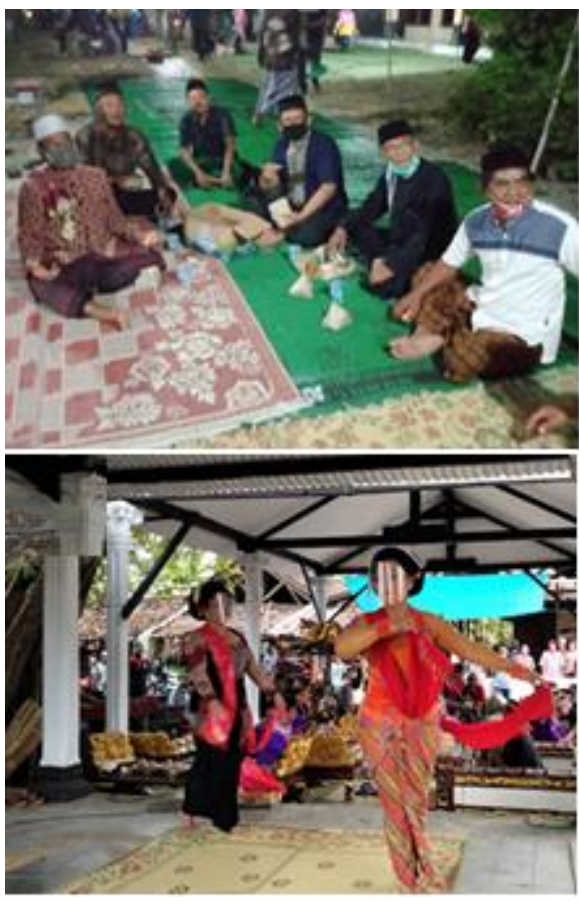

Gambar 2. Upacara sedekah bumi dilaksanakan di Punden Pujakusomo (Sumber: Koleksi Peneliti)

Masyarakat melaksanakan ritual tolak ini bertujuan untuk minta bantuan kepada Tuhan agar dijauhkan dari balak yang mengancam keberlangsungan hidup masyarakat Sedangkan upacara sedekah bumi dilaksanakan sebagai manivestasi masyarakat untuk bersyukur terhadap Tuhan Yang Maha Esa yang telah memberikan rezeki melalui bumi berupa segala bentuk hasil bumi. Dalam upacara ini disajikan sesajen berupa bubur sura (bubur sura dibuat dari berbagai biji-bijian, dimasak dalam kendi kuali dari tanah), serta berbagai jenis hasil bumi. Selain itu juga disajikan seni tayub (tayuban)

Kegiatan ritual tolak balak, sedekah bumi, dan tayuban tersebut dilaksanakan di punden desa. Di punden tersebut terdapat makam yang pendiri Desa Sirapan yaitu Ki Tejakusuma.

\section{3) Mbeleh Wedhus Kendhit Lanang}

Mbeleh Wedhus Kendhit Lanang (menyembelih kambing jantan kendhit). Wedhus kendit Lanang adalah kambing jantan dengan bulu warna hitam di seluruh tubuh, kecuali di bagian tengah perut. Bagian tengah perut atau badan berwarna putih melingkar seperti kain selendang yang dililitkan sebagai pengencang.

Warga masyarakat Desa Ngurawan Kecamatan Dolopo menyikapi pageblug dan penyebaran Covid19 dengan menggelar ritual tolak bala dengan ritual tumbal (sesaji yang dikurbankan) wedhus kendit lanang. Dipilihnya wedhus kendit lanang sebagai tumbal karena jenis kambing ini langka dan dianggap sebagai kambing yang disenangi sang gaib.

Ritual mbeleh wedhus kendhit ini dipimpin oleh pujangga (sesepuh) desa.

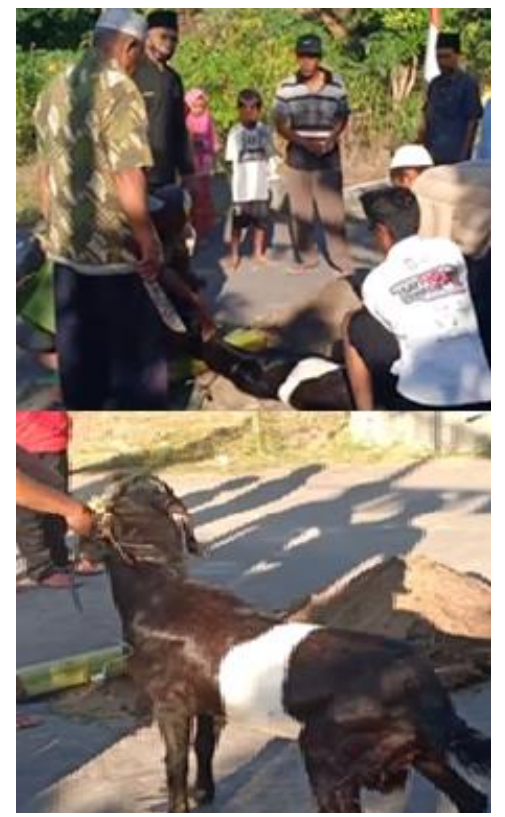

Gambar 3. Sesepuh Desa Ngurawan menyembelih kambing kendit di perempatan Desa Ngurawan Kecamatan Dolopo (Sumber: Koleksi Peneliti)

Tempat pelaksanaan ritual atau menyembelih wedhus kendhit di perempatan jalan utama Desa Ngurawan. Kegiatan di awali dengan selamatan dan berdoa agar seluruh warga masyarakat selamat dan terhindar dari Covid-19. Setelah itu pujangga beserta para sesepuh desa dan warga masyarakat menuju perempatan desa untuk menyembelih seekor kambing jantan kendit yang telah disiapkan. Bagianbagian atau organ kambing diperuntukan untuk tolak balak. Kepala kambing dibungkus kain mori putih kemudian ditanam di perempatan jalan utama desa dan satu persatu kaki kambing dibungkus kain mori warna putih kemudian ditanam di empat penjuru mata angin wilayah desa. Sedangkan badan dimasak untuk ritual kenduri atau memanjatkan doa keselamatan bagi seluruh warga desa.

\section{4) Larung Sesaji}

Sendang Tundung Madiun yang terletak di Kelurahan Kuncen. Sendang ini dalam sejarah Madiun memiliki peran penting dalam perang dengan Kerajaan Mataram Islam yang berpusat di Yogyakarta. Sendang ini oleh masyakat sekitarnya diyakini memiliki penunggu yang memiliki kekuatan sakti dan dapat dimintai bantuan. Masyarakat yang senang menjalankan ritual di sendang ini membentuk wadah dengan nama Paguyuban Sendang Tundung Madiun.

Paguyuban Sendang Tundung Madiun dalam rangka mengurangi resiko bencana akibat Covid-19 melaksanakan upacara ritual Larung Sesaji di sungai Bengawan Madiun. Prosesi ritual diawali dengan menggelar kenduri dan doa bersama di pendopo Sendang Tundung Madiun Kelurahan Kuncen 
Kecamatan Taman. Tujuannya agar masyarakat terhindar dari Covid-19.

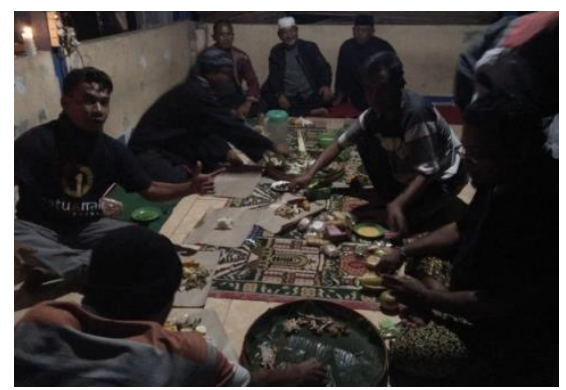

Gambar 4. Kenduri dan doa bersama di sekitar Sendang Tundung Madiun (Sumber: Koleksi Peneliti)

Ubo rampe (sesaji) yang digunakan diantaranya ayam panggang, nasi buceng, jajan pasar, buah buahan dan jenang tolak balak sengkala. Setelah berdoa makan bersama, warga masyarakat dan para sesepuh paguyuban melarung jenang hitam atau jenang sengkala ke sungai Bengawan Madiun sebagai tolak bala Covid-19.

\section{5) Dongkrekan}

Warga masyarakat Kelurahan Pandean Kecamatan Mejayan Kabupaten Madiun menggelar kesenian Dongkrek (Dongkrekan) guna menolak bala Covid-19.

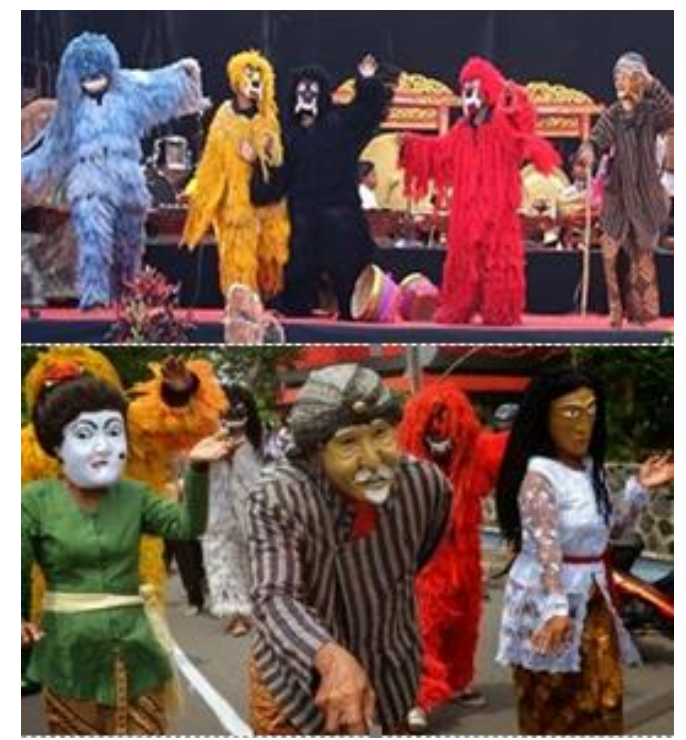

Gambar 5 Prosesi Dongkrek keliling Kelurahan Pandean (Sumber: Koleksi Peneliti)

Dongkrek yang digunakan untuk ritual tolak bala pageblug Covid-19 diawali dengan kegiatan para pemain Dongkrek menghadap sesepuh atau orang yang dituakan dalam komunitas Dongkrek. Kemudian dilanjutkan dengan kegiatan doa bersama. Doa tersebut dipanjatkan kepada Tuhan agar diberi kelematan, kesehatan, ketenteraman dan kedamaian. Kegiatan ritual selanjutnya dilakukan pada malam harinya fragmen_dongkrek dan kirab keliling desa.

Para pemain Dongkrek menggunakan topeng tokoh atau makhluk yang terlibat dalam peristiwa pageblug dan cara mengatasi. Topeng yang dimaksud yaitu Topeng Eyang Palang/Raden Prawirodipura, Topeng Nyai Rara Perot, Topeng Rara Ayu, Topeng Buto ljo, Topeng Buto Ireng, Topeng Buto ljo, Topeng Buto Kuning, dan Butho Putih. Saat tepat tengah malam tiba, rombongan Dongkrek diberangkatkan untuk keliling desa. Rombongan Dongkrek berjalan pelan-pelan menyusuri jalan-jalan di Kelurahan Pandean sambil mendendangkan lagu-lagu doa. Rombongan tersebut diiringi musik dengan instrumen utamanya yaitu bedug dan korek.

\section{b. Preduli Tangga Teparo}

Nilai-nilai kemanusian digelorakan kembali oleh tokoh-tokoh masyarakat dengan program "Preduli Tangga Teparo". Melalui program ini masyarakat disadarkan akan musibah yang dialami oleh warga lingkungan sekitar yang terpapar Covid-19 dan memotivasinya untuk memberi bantuan. Hal ini sejalan dengan falsafah hidup masyarakat yaitu memayu hayuning kulawarga lan memayu hayuning sasama Falsafah ini mengandung makna berbuat baik bagi diri sendiri, keluarga, sesama manusia. Contohnya di masyarakat Desa Mojopurno Kecamatan Wungu membantu warganya yang melaksanakan isolasi mandiri karena terpapar Covid19 dengan membantu susu, buah, sayur, dan minuman herbal. Caranya, masyarakat mencantolkan bantuan tersebut di pintu atau di pagar rumah warga yang sedang isolasi mandiri.

Selain hal tersebut di atas, tokoh-tokoh masyarakat mengedukasi warga lingkungan sekitar untuk menerima orang yang sudah sembuh dari Covid-19 sebagai bagian masyarakat dan tidak mengucilkannya. Hal tersebut direspon positif oleh warga masyarakat sehingga orang yang sudah sembuh dari Covid-19 tidak stres, depresi dan imunnya membaik.

\section{c. Gotong Royong}

Warga masyarakat, tokoh masyarakat, tokoh adat dan tokoh agama menggiatkan gotong royong dalam memutus rantai penyebaran Covid-19 dan membantu menangani imbas Covid-19. Kegiatan-kegiatan yang dilakukan diantaranya kerja bakti membersihkan lingkungan, penyemprotan disinfektan, menjaga lingkungan, dan pembatasan-pembatasan sosial, dan lain-lainnya. Hal tersebut dipredisposisi dari falsafah mereka bahwa manusia hidup harus beerbuat baik bagi diri sendiri, keluarga, sesama manusia, makhluk hidup dan seluruh dunia Contohnya; (1) Masyarakat Desa Sumberejo Kecamatan Madiun menyediakan sarana cuci tangan, membuat palang pintu ke 
wilayahnya (social distancing). Mereka melaksanakan kegiatan-kegiatan tersebut secara sukarela, baik dalam berjaga secara bergilir maupun dalam menyediakan sarana dan logistik (konsumsi), (2) Masyarakat Mejayan gotong royong mengumpulkan dana guna penyemprotan disinfektan Covid-19, (3) Forkopimda dan masyarakat membentuk "Kampung Tangguh Covid-19" diantaranya di Desa Doho Kecamatan Dagangan dan Desa Jogodayuh Kecamatan Geger (4) Masyarakat desa membentuk Satuan Tugas (Satgas) Covid-19 untuk tetap menjaga kedisiplinan, melaksanakan protokol kesehatan warga masyarakat.

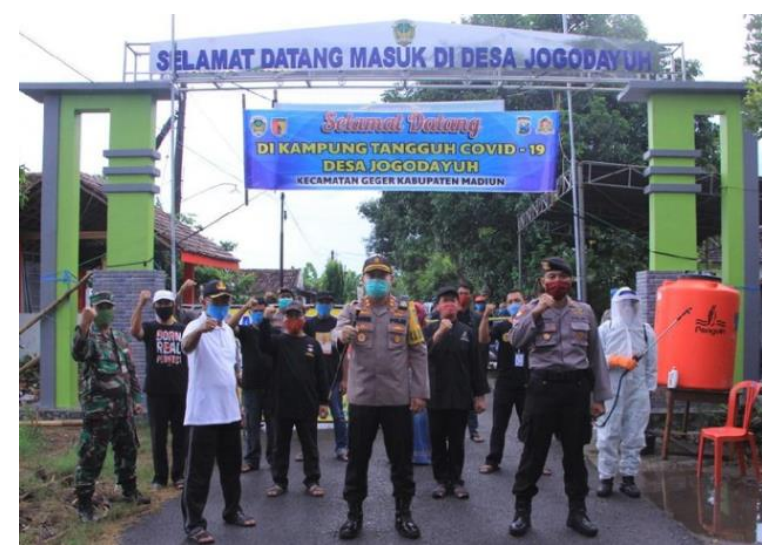

Gambar 6. Kampung Tangguh Covid-19 Desa Jogodayuh Kecamatan Geger (Sumber: Koleksi Peneliti)

\section{d. Lumbung pangan dan tanaman berkasiat}

Untuk memutus dan menangkal penyebaran Covid-19 pemerintah desa, kota/kabupaten dan propinsi melakukan pembatasan sosial dalam skala desa, kecamatan, kabupaten, dan propinsi. Menyikapi pembatasan-pembatasan sosial tersebut, masyarakat menyiapkan cadangan pangan dan tanaman obat yang berkasiat. Masyarakat menggiatkan kegiatan "Lumbung Pangan“. Lumbung pangan merupakan tempat atau bangunan untuk menyimpan padi atau bahan makanan lain untuk menghadapi masa paceklik sebagai imbas dari Covid-19. Lumbung pangan tidak hanya diperuntukan bagi dirinya sendiri dan keluarganya tetapi juga warga di lingkungan sekitarnya yang tidak mampu. Hal tersebut sebagaimana yang dilakukan masyarakat Desa Sidorejo Kecamatan Kebonsari dan Desa Joho Kecamatan Dagangan.

Untuk menopang keberadaan lumbung, masyarakat juga mengenal ganjel lumbung. Ganjel lumbung dimaksudkan tidak berupa benda sebagai ganjal atau benda yang disisipkan sebagai tumpuan supaya tegak, kukuh atau tidak timpang tetapi tanaman lain yang sebagai pengganti jika pangan di lumbung jumlah kian menipis, tidak cukup atau tidak tersedia. Tanaman tersebut dapat digunakan untuk memenuhi kebutuhan dasar akan pangan. Pemerintah dan masyarakat menggerakan Pemanfaatan Tanah Pekarangan (PTP) dengan menanam tanaman-tanaman ubi-ubian, sayuran, buah, tanaman obat (toga) dan lain-lainnya.

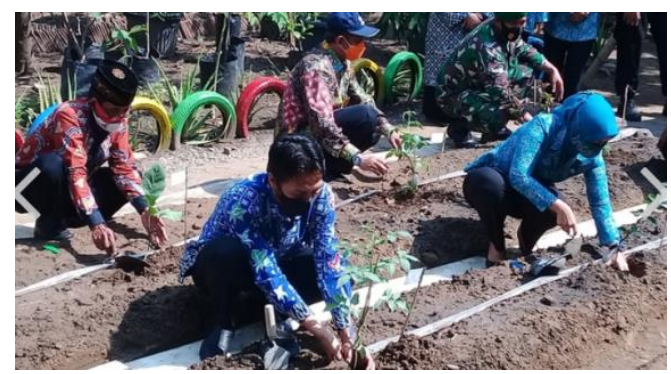

Gambar 7. Bupati Madiun bersama masyarakat Desa Mojorejo Kecamatan Kebonsari menanam tanaman di pekarangan warga masyarakat (Sumber: Koleksi Peneliti)

Kegiatan ini direspon sangat baik oleh masyarakat dengan menyiapkan ganjal lumbung dengan menanam tanaman ganjel berupa tanaman ketela, jagung, gayong, garut, dan sejenisnya. Selain itu menanam tanaman ganjel lumbung, warga masyarakat juga menanam dan mengkonsumsi tanaman, tumbuhan dan buah yang berkhasiat untuk menangkal Covid-19. Tanaman tersebut diantaranya: jahe, kunir/kunyit, lengkuas, daun sirih, daun salam, dan lain-lainnya.

Warga masyarakat melakukan aktivitas menanam dan mengkonsumsi tanama obat tersebut terkondisikan dengan adanya pembatasanpembatasan sosial, baik terbatas maupun luas. Dengan berkebun warga masyarakat dapat menghemat pengeluaran untuk memenuhi kebutuhan obat-obatan. Selain itu warga masyarakat menjadikan kegiatan ini sebagai pengusir rasa jenuh, strees, dan untuk meningkatkan imun tubuhnya.

\section{Pembahasan}

Berpijak dari hakikat kearifan lokal sebagai manifestasi dari nilai-nilai budaya yang hidup di tengah-tengah masyarakat lokal dan berfungsi sebagai referensi, rujukan dan pedoman untuk menyikapi pandemi Covid-19. Sikap masyarakat tersebut sebagai cerminan watak, kemampuan, kreativitas, dan filosofis hidupnya. Filosofi hidup menjadi prasyarat mengenali, memaknai, dan mengarifi setiap bencana. Hal tersebut sebagaimana filosofi warga masyarakat Kabupaten Madiun khususnya dan manusia Jawa untuk memayu hayuning pribadi, memayu hayuning kulawarga, memayu hayuning sasama, memayu hayuning bawana (Anshoriy\&Sudarsono, 2008).

Warga masyarakat menyikapi pandemi Covid-19 dengan melaksanakan ritual tolak balak sebagaimana disampaikan di atas menggambarkan perlunya keutuhan dan keharmonian kosmik kehidupan. Warga masyarakat untuk melepaskan ketakutan dan kecemasan pada umumnya menyandarkan pada hal-hal transendental. Dalam kosmologi yang masih membudaya dalam masyarakat Indonesia, bahwa manusia 
(mikrokosmis) agar selamat, terhindar dari bahaya, dan sejahtera perlu menjaga dan mengharmonikan melalui sikap, tindakan, dan perilakunya dengan makrokosmis (sang pencipta dan alam semesta ciptaannya).

Manusia sebagai puncak kemakhlukan yang diciptakan oleh Tuhan sebagai makhluk yang mulia dan sebaik-baiknya makhluk menjadi sumbu kosmik dalam hubungan kemestaan. Untuk itu pandemi Covid-19 beserta imbasnya merupakan kesalahan manusia sehingga manusia melaksanakan berbagai ritual untuk berhubungan dengan dunia ghaib. Hal tersebut sejalan dengan pernyataan Koentjaraningrat (1985) yaitu keyakinan dan kepercayaan mendorong manusia melaksanakan tindakan untuk mencari atau membangun hubungan dengan tuhan atau kekuatan gaib melalui ritual agar selamat dan terhindarkan dari bahaya, kesengsaraan dan penyakit. Djamari (1993) dan Wattimena (2019) juga menegaskan bahwa salah satu tujuan melaksanakan ritual yaitu untuk mendekatkan diri dan berserah kepada tuhan agar mendapatkan ketenangan, berkah, dan keselamatan.

Ritual-ritual di atas mengandung unsur doamantra, tirakat, qurban-tumbal, dan tata upacara. Dengan melaksanakan ritual tolak balak, masyarakat yakin dan optimis bahwa pandemi Covid-19 dapat ditangkal. Warga masyarakat juga merasakan bahwa rasa takut, cemas, dan panik terkurangi. Selain meningkatkan optimisme, warga masyarakat merasakan sistem imun dalam tubuhnya semakin baik.

Menolong orang yang mendapatkan musibah (preduli tangga teparo) dan gotong royong yang digiatkan dan digerakan oleh masyarakat, tokoh formal dan normal untuk memberi bantuan pada tetangga dan warga yang terpapar Covid-19, memutus rantai penyebaran, menangkal Covid-19, serta memotivasi untuk turut mengatasi imbas Covid19 sebagaimana diuraikan di atas merupakan budaya yang telah tumbuh dan berkembang dalam kehidupan sosial masyarakat Madiun khususnya dan Indonesia pada umumnya sebagai warisan budaya yang telah eksis secara turun-temurun dan diarifi. Masyarakat yang tersebar di seluruh penjuru tanah air Indonesia mengenal dan melaksanakan gotongroyong walau berbeda istilah atau sebutan namun memiliki persamaan makna. Hal ini memperkuat teori solidaritas masyarakat yang menyatakan bahwa hidup dalam tataran harmoni. Keharmonian hidup dimanivestasikan saling melindungi dan mengembangkan potensi serta saling melengkapi, asah, asih dan asuh (Rumilah, 2020),

Kata gotong royong berasal dari Bahasa Jawa yaitu gotong dan royong. Gotong berarti angkat dan royong memiliki arti bersama-sama. Jadi gotong royong dapat diartikan mengangkat sesuatu secara bersama-sama atau dapat juga diartikan mengerjakan sesuatu secara bersama-sama. Gotong royong sebagai bentuk kerja sama kelompok masyarakat untuk mencapai tujuan yang pada umumnya sebagai tindak lanjut dari hasil mufakat dan musyawarah. Gotong-royong ini dipredisposisi keinsyafan, kesadaran dan semangat untuk mengerjakan serta menanggung akibat dari suatu karya, terutama yang benar-benar, secara bersamasama, serentak dan beramai-ramai, tanpa memikirkan dan mengutamakan keuntungan bagi dirinya sendiri, melainkan selalu untuk kebahagian bersama. Hal ini sejalan dengan hasil penelitiannya Parera dan Marzuki (2020) yakni kearifan lokal yang berupa gotong royong menjadi sumber kekuatan dalam mewujudkan kehidupan masyarakat yang kondusif, baik dalam konteks kehidupan manusia sebagai individu dengan individu, maupun individu dengan komunitas.

Secara instrinsik preduli tangga teparo dan gotong-royong dapat diwujudkan dengan baik jika dilandasi dengan semangat keihklasan, kerelaan, kebersamaan, toleransi dan kepercayaan. Hal ini sejalan dengan pendapat Kartodirdjo (1987) bahwa gotong-royong menggambarkan usaha bersama, suatu amal, suatu pekerjaan atau suatu karya bersama, suatu perjuangan bantu-membantu. Gotong-royong dinilai sebagai amal dari semua untuk kepentingan semua atau jerih payah dari semua untuk kebahagian bersama. Dalam azas gotongroyong tersimpul kesadaran bekerja rohaniah maupun kerja jasmaniah dalam usaha atau karya bersama yang mengandung keinsyafan, kesadaran dan sikap jiwa untuk menempatkan serta menghormati kerja sebagai kelengkapan dan perhiasan kehidupan. Hal tersebut digarisbawahi oleh Effendi (2013) yaitu gotong-royong secara prinsip mengandung nilai-nilai kearifan yang melekat subtansi nilai-nilai ketuhanan, musyawarah dan mufakat, kekeluargaan, keadilan dan toleransi (peri kemanusiaan) yang merupakan basis pandangan hidup atau sebagai landasan filsafat masyarakat Indonesia.

Gotong-royong sebagai azas bersifat dinamis sehingga pemaknaannya tidak terbingkai pada makna yang kaku yaitu gotong-royong kerja bakti saja tetapi juga gotong-royong tolong menolong kegiatan bertetangga dan ber bermasyarakat pada peristiwa bencana. Untuk itulah gotong-royong menjadi modal sosial dan sendi kehidupan yang dijadikan prinsip masyarakat dalam menyikapi pandemi Covid-19.

Masyarakat menyiapkan cadangan pangan dan tanaman obat yang berkasiat sedikit banyak diilhami dari budaya masyarakat pendahulu (nenek moyang) bangsa Indonesia. Dalam kehidupan yang bertumpu pada agraris, warga masyarakat diwarisi tata kelola hidup untuk memenuhi kebutuhan dasar pangan minimal satu musim atau sebelum panen berikutnya dan jika terjadi bencana (paceklik) yaitu sistem lumbung dan ganjel lumbung. Lumbung pangan pada umumnya digunakan untuk menyimpan hasil-hasil pertanian terutama padi. Lumbung ada yang dikelola oleh keluarga (lumbung keluwarga) dan ada juga 
yang dikelola oleh masyarakat desa (lumbung desa). Bila musim panen tiba maka sebagian hasil panenannya disimpan di lumbung. Pangan yang tersimpan diambil secara bertahap dan disesuaikan dengan kebutuhan termasuk untuk dipinjamkan pada warga dan menghadapi gagal panen atau paceklik. Jika musim panen akan tiba dan pangan di lumbung masih ada/tersedia maka akan diturunkan dan dijual atau diperuntukan hal lain sesuai kebutuhan.

Untuk menopang keberadaan lumbung, masyarakat juga mengenal ganjel lumbung. Ganjel lumbung dimaksudkan tidak berupa benda sebagai ganjal atau benda yang disisipkan sebagai tumpuan supaya tegak, kukuh atau tidak timpang tetapi tanaman lain yang sebagai pengganti jika pangan di lumbung jumlah kian menipis, tidak cukup atau tidak tersedia. Tanaman tersebut dapat digunakan untuk memenuhi kebutuhan dasar akan pangan. Masyarakat Kabupaten Madiun menyiapkan ganjal lumbung dengan menanam tanaman ganjel berupa tanaman ketela, jagung, gayong, garut, dan sejenisnya.

Masyarakat Kabupaten Madiun dalam menyikapi pandemi Covid-19 terinpirasi dari para pendahulu tentang pertabiban dan obat-obatan herbal dan mengedukasi keluarga dan masyarakat tentang tanaman obat. Wilayah kabupaten ini memiliki banyak tanaman yang dapat dijadikan obat, berkhasiat, dan diwariskan secara turun menurun. Untuk itu warga masyarakat menanam dan mengkonsumsi tanaman, tumbuhan dan buah yang berkhasiat untuk menangkal Covid-19.

Dengan dengan demikian bentuk-bentuk kearifan lokal masyarakat Madiun dalam menyikapi Pandemik Covid-19 sebagaimana disampaikan di atas perlu dilestarikan karena dapat dijadikan sebagai sumber inspirasi dalam menyikapi bencana seperti Covid-19.

\section{KESIMPULAN}

$\mathrm{M}$ asyarakat Kabupaten Madiun melaksanakan mitigasi dalam menghadapi pandemi Covid19 dengan menyandarkan pada kearifan lokal memayu hayuning pribadi, memayu hayuning kulawarga, memayu hayuning sasama, memayu hayuning bawana. Adapun bentuk kearifan local dalam menyikapi pandemi ini antara lain; (1) Melakukan ritual keagamaan. Ritual menjadi sandaran transendental masyarakat lokal dalam melepaskan segala ketakutan, kecemasan, dan kepanikan. Ritual keagamaan ini mengedukasi dan mentransformasi tentang kearifan diri untuk tidak takut dan cemas dan penguatan dengan "energi spiritual" yang berujung semangat dan meningkat imun tubuhnya, (2) Melaksanakan gerakan preduli tangga teparo. Gerakan ini menyadarkan masyarakat akan nasib sesamanya yang mendapat musibah dan membantunya. (3) Melaksanakan gotong-royong. Gotong-royong menggambarkan bahwa warga masyarakat tidak sendirian dalam menghadapi Covid-19 karena mereka bekerja sama dilandasi kesadaran untuk menempatkan serta menghormati kerja sebagai kelengkapan dan perhiasan kehidupan serta dapat menyatukan warga masyarakat untuk saling asah, asih, dan asuh. (4) Menggiatkan dan mengerakan lumbung pangan dan tamaman obat. Lumbung pangan sebagai cara yang dilakukan masyarakat dengan menyediakan bahan pangan ketika bencana. Masyarakat bergerak untuk menyiapkan ganjel lumbung sebagai bahan pangan pengganti jika bahan pangan pokok tidak mencukupi atau tidak tersedia. Selain itu, masyarakat menanam tanaman obat dan mengkonsumsinya untuk meningkatkan imun agar tidak mudah terserang Covid-19.

Kearifan lokal telah mengeduksi dan menginpirasi bagaimana kekuatan manusia Indonesia menghadapi cobaan. Oleh karena tak ada salahnya kalau mengkontemplasinya dan sadar betapa pentingnya kearifan lokal dalam menghadapi Covid-19. Jalani masa pandemi ini dengan mangasah mingising budi, mamasuh malaning bumi (mengasah ketajaman budi, membasuh mapapetaka bumi) dan niteni, nirokke, lan nambahi (mengamati, meniru, menambahi / 3M) .

\section{E. UCAPAN TERIMAKASIH}

T erima kasih penulis sampaikan kepada Rektor dan Kepala LPPM Universitas PGRI Madiun atas fasilitasinya untuk melaksanakan riset ini, Hal serupa juga penulis sampaikan kepada para kepala desa atas pemberian ijinnya. Tokoh-tokoh masyarakat, rohaniawan, dan para informan atas keterangannya sehingga penelitian/penulisan artikel ini dapat diselesaikan sesuai rencana.

\section{DAFTAR PUSTAKA}

Ahmadi, A. (2007). Psikologi Sosial. Jakarta: Rineka Cipta.

Anshoriy, N., \& Sudarsono. (2008). Kearifan Lingkungan dalam Perspektif Budaya Jawa. Jakarta: Yayasan Obor Indonesia.

Baron, R.A dan Byrne, D. (2004). Psikologi Sosial. (R. Djuwita, Ed.). Jakarta: Airlangga.

BPS. (2020). Sosial dan Kependudukan Kabupaten Madiun dalam Angka. Badan Pusat Statistik Kabupaten Madiun. Diambil dari https://madiunkab.bps.go.id/subject/153/geografi.html\#subjekViewTab3. Diunduh 10 Agustus 2020 
Casram, C., Dadah, D. (2019). Posisi Kearifan Lokal Dalam Pemahaman Keagamaan Islam Pluralis. Religious: Jurnal Studi Agama-Agama dan Lintas Budaya, 3(2), 161-187. Diambil dari https://journal.uinsgd.ac.id/index.php/Religious/article/view/4739/pdf. Diunduh 4 Januari 2020

Creeswell, J. W. (2014). Penelitian Kualitatif\&Desain Riset. (S. Z. Qudsy, Ed.) (3 ed.). Yogyakarta: Pustaka Pelajar.

Darmastuti, R. (2012). Kearifan Lokal Masyarakat Indonesia dalam Menghadapi Terpaan Media. In Literasi Media \& Kearifan Lokal "Konsep dan Aplikasi" (2 ed., hal. 50-84). Salatiga: Mata Padi Presindo. Diunduh 5 Maret 2019

Djamari. (1993). Agama dalam Perspektif Sosiologi. Bandung: Alfabeta.

Effendi, T. N. (2013). Budaya Gotong-Royong Masyarakat dalam Perubahan Sosial Saat Ini. Jurnal Pemikiran Sosiologi, 2(1), 1-18.

Fanani, A. (2020). Lagu Corona Dinilai Lukai Banyak Pihak, Pedangdut Ini Rilis Obatnya. Diambil dari https://news.detik.com/berita-jawa-timur/d-4928814/lagu-corona-dinilai-lukai-banyak-pihak-pedangdut-inirilis-obatnya. Diunduh 1 April 2020

Geertz, C. (1983). Local Knowledge; Further Essays in Interpretative Anthropology. New York: Basic Books.

Greenberg, J., \& Baron, R. A. (2003). Behavior in Organization (8 ed.). New Jersey: Prentice Hall.

Habibi, R.K., Kusdarini, E. (2020). Kearifan Lokal Masyarakat dalam Melestarikan Tradisi Pernikahan Pepadun di Lampung Utara. Jurnal Antropologi: Isu-isu Sosial Budaya, 22(01), 60-69. https://doi.org/https://doi.org/10.25077/jantro.v22.n1.p60-69.2020. Diunduh 1 Agustus 2020

Hanif, M., Retno, R. S. (2019). Akon-akon kambing as a methods of empowering disability: Local wisdom studies. International Journal of Scientific and Technology Research, 8(11), 427-433. Diambil dari http://www.ijstr.org/final-print/nov2019/Akon-akon-Kambing-As-A-Methods-Of-Empowering-DisabilityLocal-Wisdom-Studies.pdf. Diunduh 5 Januari 2020

Hannan, Abd., Trianingsih, H. (2020). Mitigasi Covid-19 Melalui Kearifan Lokal Pesantren di Madiura. Islamika Inside: Jurnal Keislaman dan Humaniora, 6(2), 1-30.Diunduh 4 Mei 2020.

Hanurahman, F. (2012). Psikologi Sosial Suatu Pengantar. Bandung: PT Remaja Rosdakarya.

Ismail, N., Bakhtiar, B., Yanis, M., Darisma, D., Abdullah, F. (2020). Mitigasi dan Adaptasi Struktural Bahaya Banjir Berdasarkan Kearifan Lokal Masyarakat Aceh Singkil Provinsi Aceh. Jurnal Antropologi: Isu-isu Sosial Budaya, 22(02), 276-285. https://doi.org/https://doi.org/10.25077/jantro.v22.n2.p276-285.2020, diunduh 5 Januari 2021.

Kartodirdjo, S. (1987). Gotong Royong: Saling Menolong dalam Pembangunan Masyarakat Indonesia. In N. J. Colett \& U. Khayam (Ed.), Kebudayaan dan Pembangunan Sebuah Pendekatan terhadap Antropologi Terapan Ilmu Pengetahuan Sosial di Indonesia. Jakarta: Yayasan Obor.

Kluckhohn, F. (1991). Variation In Value Orientation. Harvard University Press.

Koentjaraningrat. (1985). Beberapa Pokok Antropologi Sosial (6 ed.). Jakarta: P.T. Dian Rakyat.

Koentjaraningrat. (2009). Pengantar Antropologi (Edisi Revisi 2009). Jakarta: Rineka Cipta.

Parera, M.M.A.E., dan Marzuki, M. (2020). Kearifan Lokal Masyarakat dalam Membangun Kerukunan Umat Beragama di Kota Kupang, Nusa Tenggara Timur. Jurnal Antropologi : Isu-isu Sosial Budaya, 22(01), 3847. https://doi.org/https://doi.org/10.25077/jantro.v22.n1.p38-47.2020. Diunduh 5 Agustus 2020

Raharjo, T. (2005). Menghargai Perbedaan Kultural: Mainfulness dalam Komunikasi Antaretnis. Yogyakarta: Pustaka Pelajar.

Rahman, A. A. (2013). Psikologi Sosial, Integrasi Pengetahuan Wahyu dan Pengetahuan Empirik. Jakarta: PT RajaGrafindo Persada.

Rumilah, S. dkk. (2020). Kearifan Lokal Masyarakat Jawa dalam Menghadapi Pandemi. SULUK: Jurnal Bahasa, Sastra, dan Budaya, 2(2), 119-129. https://doi.org/https://doi.org/10.15642/suluk.2020.2.2.119129. 3 Januari 2021

Soekanto S., dan Sulistyowati, B. (2014). Sosiologi Suatu Pengantar, (Edisi Revisi) (46 ed.). Jakarta: PT RajaGrafindo Persada.

Soetomo. (2012). Keswadayaan Masyarakat. Yogyakarta: Pustaka Pelajar.

Strauss, A. dan Corbin, J. (1990). Basic off qualitative research: Grounded theory and procedure and techniques. Newbury Park, CA: Sage.

Theresia, A. (2014). Pembangunan Berbasis Masyarakat (1 ed.). Bandung: Alfabeta.

Wales, H. . (1958). The Mountain of God: A Study in Early Religion and Kingship. London: Bernard Quaritch Itd.

Walgito, B. (2011). Psikologi Sosial Sebuah Pengantar. Yogyakarta: CV Andi Offset.

Wattimena, R. A. A. (2019). Untuk Semua yang Beragama, Agama dalam Pelukan Filsafat, Politik, dan Spiritualitas. Yogyakarta: PT Kanisius. 